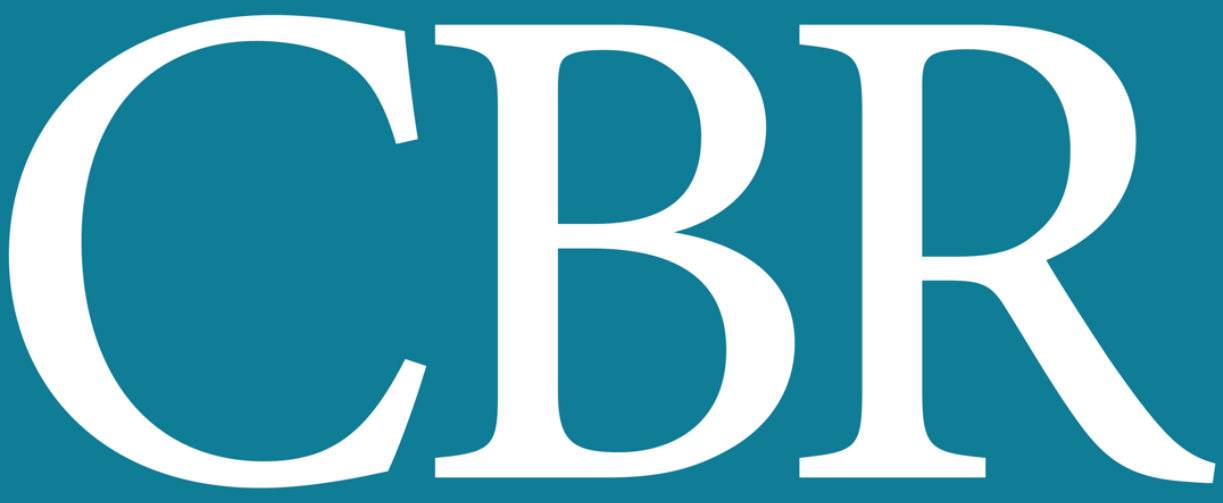

INTERNATIONAL JOURNAL OF CANCER AND BIOMEDICAL RESEARCH

https://jcbr.journals.ekb.eg

Editor-in-chief

Prof. Mohamed Labib Salem, PhD

Farming and pastoral systems shape the physiological and immunological indices of the dromedary she-camels

Asmaa S. Atta, Ibrahim El-Shourbagy, Hamdy A. Gawish, Hassan A. ElMetwaly, Fawzy E. Younis and Mohamed L. Salem 


\section{Welcome letter from Editor-in-Chief}

Welcome to the Int J Cancer and Biomedical Research (IJCBR)!

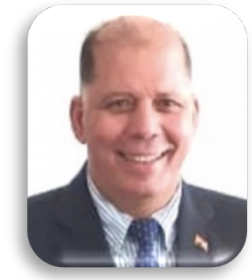

It is with great pleasure that I write this editorial to welcome you to the IJCBR. This journal provides a platform for publication of original and reviews research articles, short communications, letter to editor, thesis abstract, conference report, and case studies. These types of publication are directed at the interface of the fields of cancer and biomedical research.

The IJCBR relies on a distinguished expert of the Advisory and Editorial Board Members from the top international league covering in depth the related topics. They timely review all manuscripts and maintain highest standards of quality and scientific methodology and ethical concepts. Meanwhile, we take all possible means to keep the time of the publication process as short as possible.

I take this chance to welcome your contributions to the IJCBR and have every expectation that it will soon become one of the most respected journals in both the fields of cancer and biomedical research.

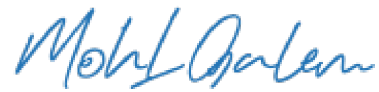

Mohamed L. Salem,

Editor in Chief 


\title{
Farming and pastoral systems shape the physiological and immunological indices of the dromedary she-camels
}

\author{
Asmaa S. Atta ${ }^{1}$, Ibrahim El-Shourbagy ${ }^{2}$, Hamdy A. Gawish ${ }^{1}$, Hassan A. El-Metwaly ${ }^{3}$, Fawzy E. Younis ${ }^{1}$ and \\ Mohamed L. Salem ${ }^{2}$ \\ ${ }^{1}$ Animal and Poultry Physiology Department, Desert Research Center, Cairo, Egypt \\ 2Zoology Department, Faculty of Science, Tanta University, Tanta, Egypt \\ ${ }^{3}$ Camel Research Department, Animal Production Research Institute, Giza, Egypt
}

\section{ABSTRACT}

Background: Camel (Camelus dromedarius) is a vital animal to the daily life of the desert as a source of food and transportation, its milk is used as medicine for diverse ailments. Aim: This study was planned to evaluate the effect of two different feeding systems (farming and pastoral systems) on physiological and immunological indices of one-humped dromedary she-camels during different physiological stages. Material and methods: Forty female camels under farm and grazing systems were used from the Camel Experimental Flock in Matrouh (farming system) and Bedouin flock in a grazing unit in the same area (pastoral system). Blood samples were collected during different physiological stages to determine the desired parameters. Results: It was revealed that lymphocytes significantly increased in grazing camels as compared to farm ones. Leukocytes significantly increased in post-partum and lactation than other camels. The number of RBCs increased significantly in pregnant and lactating than other camels. Albumin increased significantly in pregnant and lactating camels and decreased in dry and post-partum. Results showed a significant increase in blood lipids including total lipids, phospholipids, triglycerides, total cholesterol, and low-density lipoproteins in farm camels compared to grazing ones. Lactating and pregnant camels showed a significant increase in cholesterol compared to dry and post-partum. In lactating camels, insulin significantly increased compared to other groups. But, cortisol significantly increased in post-partum camels. Conclusion: Farm camels show better physiological and immunological profiles than grazing ones reflect the importance of supplementary feeding especially during pregnancy and lactation.

Editor-in-Chief: Prof. M.L. Salem, PhD - Article DOI: 10.21608/JCBR.2020.49275.1092

\section{ID ARTICLE INFO}

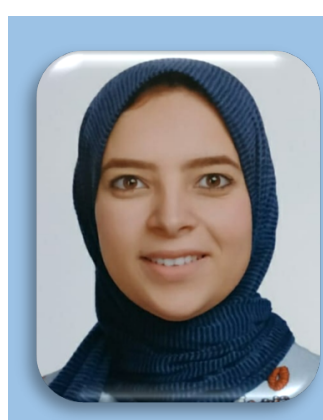

Article history

Received: July 14, 2020

Revised: August 29, 2020

Accepted: September 5, 2020

Correspondence to:

Dr. Asmaa S. Atta

Animal and Poultry Physiology

Department,

Desert Research Center, Egypt

Te.: (+20) 1004541981

Email:

asmaa1shaaban@gmail.com

\section{INTRODUCTION}

The camel (Camelus dromedarius) is an important component of the desert ecosystem, which plays an important role within the pastoral and agriculture system in the NorthWestern Coast Zone (NWCZ). According to FAO (2013) the total population of camels worldwide is believed to be 25.89 million, of which $89 \%$ are one-humped dromedary camels (Camelus dromedarius). The remaining $11 \%$ are the twohumped (Camelus bactrianus) that are generally found in the cold deserts of Asia. While, more than $60 \%$ of the dromedary camel population is concentrated in the arid areas of North East African countries like Somalia, Sudan, Ethiopia, and Kenya (Simeneh, 2015).
The dromedary camels have very special anatomical and physiological characteristics, which enable the animals to live, reproduce and produce milk and meat and to work under extreme conditions of heat and aridness - even during periods of drought when cattle, sheep, and goats rarely survive (Abdalmula et al., 2018).

The camel production system in the study area is mainly extensive and depends mainly on grazing on natural rangelands. While camels in the farming system are reared under an intensive system. Concentrate mixture (14\% crude protein (CP), $10.5 \%$ digestible crude protein (DCP), and $65 \%$ total digestible nutrients (TDN)) is offered to the camels and water is 
available all day time (Faye, 2016a,b). Complementary feeding is widely practiced in the area due to the low and erratic rainfall. The period of complementary feeding is 4.5. 6.1 and 9.0 months in good, average and poor seasons, respectively (Bhakat, 2019).

It is well known that clinical examination, hematological and biochemical profiles have a direct relation with the health, nutritional and physiological status of the camel (Tharwat et al., 2015). So, they are very important tools for monitoring female camels during different physiological stages (pregnancy, parturition, and lactation) since they are considered metabolic stresses (Omidi et al., 2014).

On the other hand, dromedaries can adapt to dry and harsh conditions in arid areas. They take their protein requirements that perform their various physiological functions from the protein content of plant species during grazing. The difference in water intake and available plants has a direct influence on the physiological functions and blood constituents of camels (Warden, 2004; Babeker et al., 2013).

Therefore, this work aims to evaluate and study the effect of farming and pastoral systems on physiological responses (hematological, biochemical parameters as well as some hormones) of female dromedary camels during different physiological stages (dry, pregnant, post-partum, and lactating)

\section{MATERIAL AND METHODS}

This study was carried out at Matrouh Technical Support Unit (TSU) of the Sustainable Development Center for Matrouh Resources (SDCMR), belonging to Desert Research Center (DRC), representing the extensive system and the Center for the Study and Development of camels in Marsa Matrouh that belongs to Animal Production Research Institute (APRI), Agricultural Research Center (ARC), representing the intensive system. Both DRC and ARC belong to the Ministry of Agriculture and Land Reclamation (MALR), Cairo, Egypt.

\section{Animals}

This study was performed on 40 female camels (Camelus dromedarius); 20 female camels (10 pregnant and 10 dry) were chosen randomly from ARC Experimental Station Farm and another 20 female camels ( 10 pregnant and 10 dry) were randomly chosen from grazing camels supported by the TSU of DRC as shown in Figure 1. Pregnant camels, in the last two months of pregnancy, were randomly chosen from the pregnant females in the two management systems with live body weight ranged from 474 to 593 and 458 to $589 \mathrm{Kg}$ for farming and grazing systems, respectively. The corresponding live body weight of the other 20 adult nonpregnant non-lactating dry female camels was 425 to 438 $\mathrm{Kg}$ in the farm and 382 to $428 \mathrm{Kg}$ in the grazing unit. Female camels were followed up during the late pregnancy phase, post-partum phase, and lactation stage.

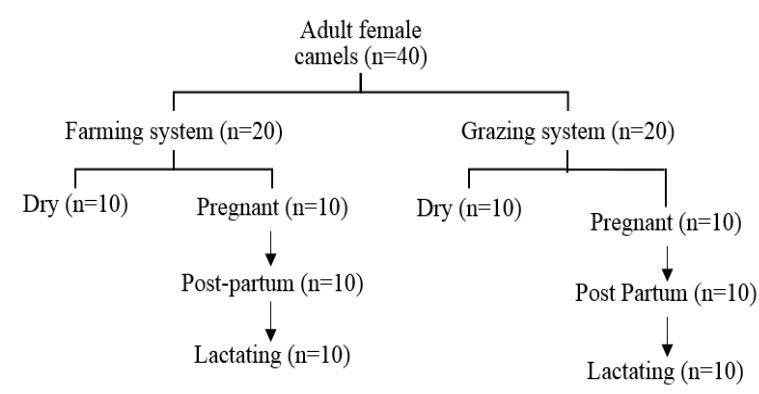

Figure 1. Experimental design of farm and grazing camels.

\section{Feeding system}

Under the farming system, camels were reared under an intensive system where they fed twice daily with a basal diet consisted of $3.5 \mathrm{~kg}$ concentrate feed mixture (CFM) with $16 \%$ protein plus $2.5 \mathrm{~kg}$ berseem hay (BH) and $2.5 \mathrm{~kg}$ rice straw (RS) per animal. The CFM consisted of $25 \%$ wheat bran, $25 \%$ yellow corn, 9\% uncorticated cottonseed meal, $20 \%$ barely, $15 \%$ rice bran, $3 \%$ molasses, $2 \%$ premix and $1 \%$ common salt. Water was available all daytime. All animals were healthy and were kept under semi-open pens in the farm. Other twenty adult female camels were randomly chosen from the flock which is grazing in the desert. The camel production system in such an area is mainly extensive and depends on grazing on natural rangelands. Camel herds move across a distance of 50-100 km daily seeking the range plants to fulfill their requirements. Natural rangelands of the NWCZ consist of a variety of herbs, grasses, bushes, and trees. 
The average grazing time is around 9.6 hours in winter and extends to 19.4 hours during summer. During the rainy season, the herbage is often rich in water and the camels will also find surface water in natural dams. During the winter and cool season (6-7 months) in the Sahara, the camels can go without water. The fodder has enough moisture for the maintenance and production requirements. All animals were healthy and were let to graze all day. They were kept in completely open pens in the evening and all night. Water was available all day in the rainy days and every week on dry days. Parameters were measured in the late pregnancy phase, post-partum phase, lactating phase and non-lactating (dry) phase.

\section{Blood sampling}

Blood samples $(5 \mathrm{ml})$ were taken out from the jugular vein (at 6:00 am) before morning feeding; one part was poured in tubes containing EDTA as an anticoagulant and used for CBC. The other part was taken in tubes free of any anticoagulant. Serum and plasma samples were collected after separation by centrifugation at $3000 \mathrm{rpm}$ for $15 \mathrm{~min}$ and stored at $-20 \stackrel{\circ}{ } \circ$ for biochemical analysis.

The hematological parameters comprising leukocytes (WBCs) as well as, relative and absolute numbers of lymphocytes, monocytes and granulocytes were manually determined. In addition, the total number of red blood corpuscles (RBCS) and hemoglobin ( $\mathrm{Hb}$ ) content were estimated after collecting fresh blood samples according to Schalm et al. (1975).

Levels of total protein (TP, g/dl), albumin (AL, $\mathrm{g} / \mathrm{dl}$ ), total lipids ( $\mathrm{TL}, \mathrm{mg} / \mathrm{dl}$ ), Phospholipids (PL, $\mathrm{mg} / \mathrm{dl}$ ), Triglycerides (TG, $\mathrm{mg} / \mathrm{dl}$ ), total cholesterol (TC, mg/dl), LDL Cholesterol (LDL-C, $\mathrm{mg} / \mathrm{dl}$ ), HDL Cholesterol (HDL-C, $\mathrm{mg} / \mathrm{dl}$ ) and glucose ( $\mathrm{Glu}, \mathrm{mg} / \mathrm{dl}$ ) were determined in blood plasma using commercial kits supplied from Biodiagnostic Company $(\mathrm{GmbH} \&$ Co., Germany). The value of globulin (GL) was calculated by subtracting the value of AL from the value of TP. A/G ratio was also calculated by dividing the value of $A L$ by the value of $G L$.

\section{Hormonal assay}

Concentrations of Insulin (Ins, $\mu \mathrm{U} / \mathrm{ml}$ ) and Cortisol (Cort, $\mu \mathrm{g} / \mathrm{ml}$ ) hormones in milk were determined automatically by ADVIA Centaur ${ }^{\circ}$ XP System from Siemens Healthcare Diagnostics Inc., Laboratory Diagnostics, USA.

\section{Statistical analysis}

Numerical data obtained from each experiment were expressed as means \pm SE. Data obtained was analyzed using the General Linear Model (GLM) of SAS (2003) software package. Statistical means were compared using Duncan Multiple Range Test (DMRT) (Duncan, 1955). The difference was considered significant at $\mathrm{P}<0.005$.

\section{RESULTS}

\section{Hematological Parameters}

\section{Absolute and relative values of leukocytes}

Data in Figures 2-4 revealed that the management system had an insignificant effect on the leukocytic count and its differential count except for the number of lymphocytes which increased significantly $(P<0.05)$ in grazing camels $\left(6.62 \times 10^{3}\right.$ vs. $\left.5.5 \pm 0.49 \times 10^{3} / \mathrm{mm}^{3}\right)$ compared to farm ones. On the other hand, the physiological status had a significant $(P<0.05)$ effect on the number of WBCs, lymphocytes, neutrophils and monocytes, as well as, the percentage of lymphocytes, neutrophils and eosinophils. Leukocytes increased $(P<0.05)$ in post-partum $\left(15.77 \pm 1.2 \times 10^{3} / \mathrm{mm}^{3}\right)$ compared to pregnant $\left(8.39 \pm 0.8 \times 10^{3} / \mathrm{mm}^{3}\right)$ and dry camels $\left(8.87 \pm 0.7 \times 10^{3} / \mathrm{mm}^{3}\right)$.

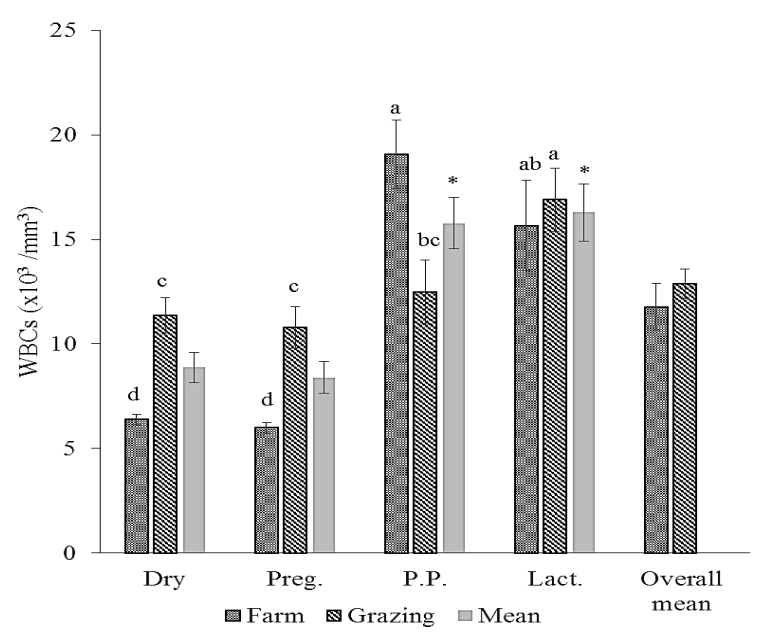

Figure 2. Effect of interaction between physiological stage and feeding system on total leukocytes number. Data were represented as means $\pm \mathrm{SE}$. ${ }^{*}, \# \mathrm{P} \leq 0.05,{ }^{*}$, \# $\mathrm{P} \leq 0.01$. Different superscripts on columns for each parameter means that they are significantly different at $P<0.05$. Preg.= Pregnant; P.P= Post-partum; Lact. $=$ Lactating. 

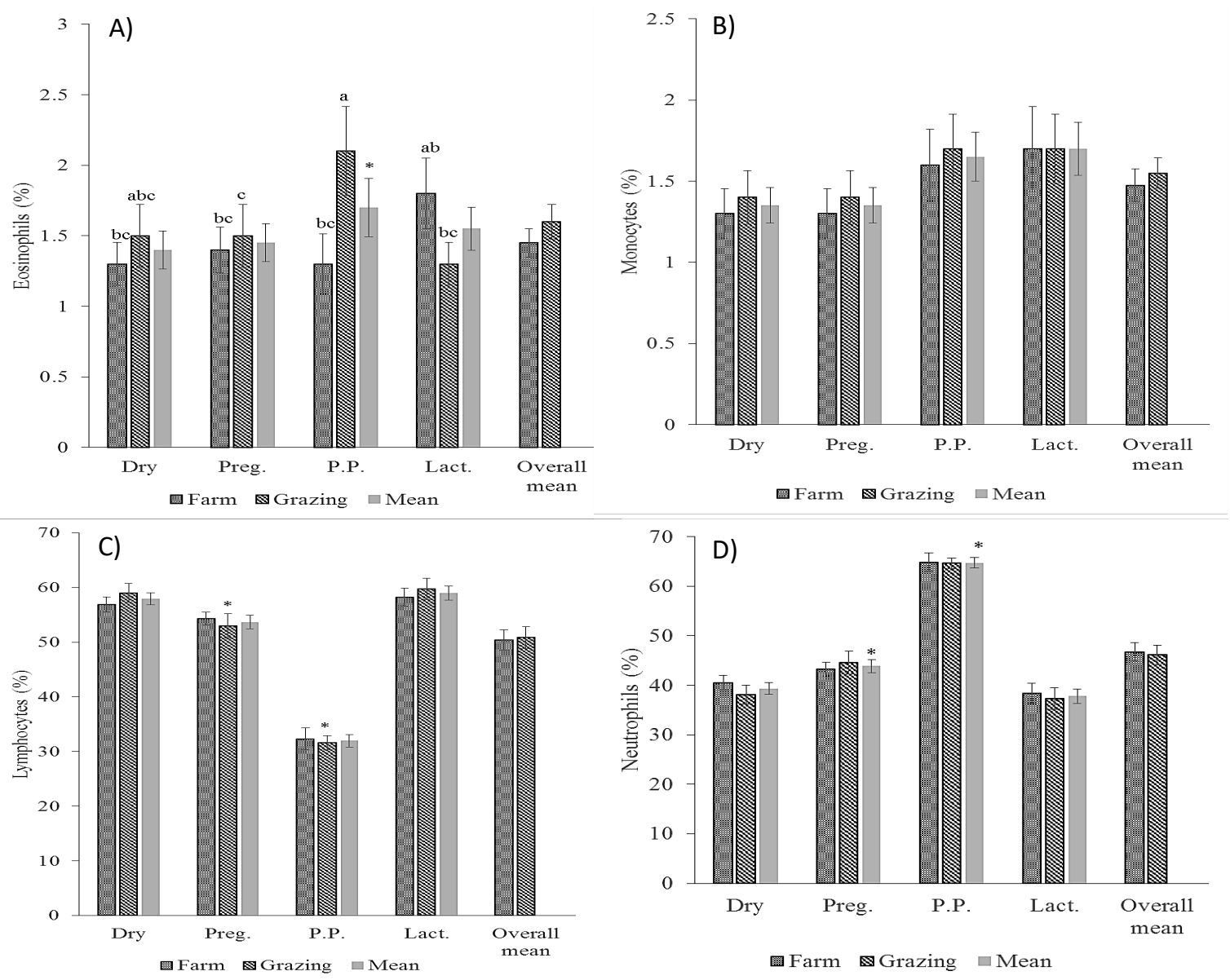

Figure 3. Effect of interaction between physiological stage and feeding system on the relative number of lymphocytes (A), neutrophils (B), eosinophils (C) and monocytes (D). Data were represented as means $\pm S E .{ }^{*}, \# P \leq 0.05,{ }^{* *}, \# \# \leq 0.01$. Different superscripts on columns for each parameter means that they are significantly different at $P<0.05$. Preg.= Pregnant; $P . P=P$ ostpartum; Lact.=Lactating.

While lactating camels have a significant $(P<0.05)$ increase in leucocytes $\left(16.28 \pm 1.4 \times 10^{3}\right.$ $\left./ \mathrm{mm}^{3}\right)$ than dry $\left(8.87 \pm 0.7 \times 10^{3} / \mathrm{mm}^{3}\right)$ and pregnant $\left(8.39 \pm 0.8 \times 10^{3} / \mathrm{mm}^{3}\right)$ and slight increase than post-partum $\left(15.77 \pm 1.2 \times 10^{3}\right.$ $/ \mathrm{mm}^{3}$ ). In addition, there are an increase $(P<0.05)$ in the percentage of lymphocytes in lactating (58.95 $\pm 1.26 \%)$ and dry camels $(57.95 \pm 1.2 \%)$ than pregnant $(53.65 \pm 1.25 \%)$ ones whereas it decreased $(P<0.05)$ in postpartum camels ( $31.95 \pm 1.17 \%)$. The percentage of neutrophils increased $(P<0.05)$ after parturition $(64.7 \pm 1.04 \%)$ and decreased $(P<0.05)$ in pregnant $(43.85 \pm 1.31 \%)$, lactating $(37.8 \pm 1.45 \%)$ and dry camels $(39.3 \pm 1.92 \%)$, respectively. The number of lymphocytes showed an increase $(P<0.05)$ in lactating camels $\left(9.48 \pm 0.75 \times 10^{3} / \mathrm{mm}^{3}\right)$ and decreased $(P<0.05)$ in dry $\left(5.17 \pm 0.45 \times 10^{3} / \mathrm{mm}^{3}\right)$, pregnant $\left(4.51 \pm 0.53 \times 10^{3} / \mathrm{mm}^{3}\right)$ and postpartum $\left(5.09 \pm 48 \times 10^{3} / \mathrm{mm}^{3}\right)$. Post-partum camels showed a significant $(P<0.05)$ increase in the number of neutrophils $\left(10.18 \pm .79 \times 10^{3} / \mathrm{mm}^{3}\right)$ then decreased $(P<0.05)$ in lactating $(6.31 \pm 0.68$ $\left.\mathrm{x} 10^{3} / \mathrm{mm}^{3}\right)$, as well as, a decrease $(P<0.05)$ in dry $\left(3.45 \pm 0.29 \times 10^{3} / \mathrm{mm}^{3}\right)$ and pregnant $\left(3.67 \pm 0.36 \times 10^{3} / \mathrm{mm}^{3}\right)$ than other two groups. The physiological status affected significantly $(P<0.05)$ the percentage and number of eosinophils which increased significantly $(P<0.05)$ in post-partum $(1.7 \pm 0.21 \%$ and $\left.0.25 \pm 0.02 \times 10^{3} / \mathrm{mm}^{3}\right)$ and lactating $(1.55 \pm 0.15$ $\%$ and $\left.0.23 \pm 0.02 \times 10^{3} / \mathrm{mm}^{3}\right)$ and decreased significantly $(P<0.05)$ in pregnant $(1.25 \pm 0.14 \%$ and $0.1 \pm 0.01 \times 10^{3} / \mathrm{mm}^{3}$ ) and dry camels $\left(1.4 \pm 0.13 \%\right.$ and $\left.0.13 \pm 0.02 \times 10^{3} / \mathrm{mm}^{3}\right)$. Lactating and post-partum camels showed an increase $(P<0.05)$ in the number of monocytes compared to dry and pregnant camels $\left(0.26 \pm 0.03\right.$ and $0.26 \pm / \mathrm{mm}^{3}$ vs. 0.12 and 0.12 $\mathrm{x} 10^{3} / \mathrm{mm}^{3}$, respectively). 

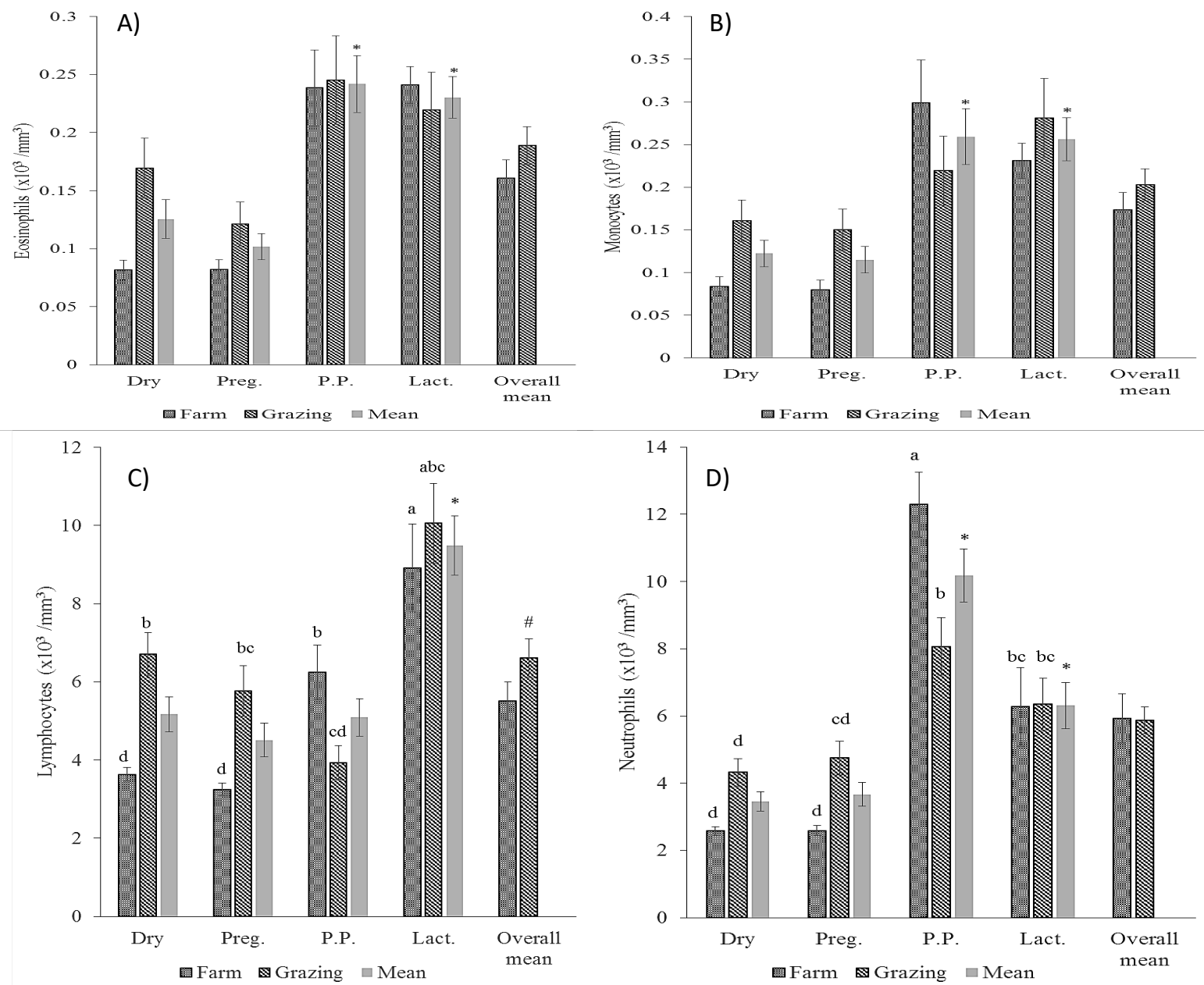

Figure 4. Effect of interaction between physiological stage and feeding system on the absolute number of lymphocytes (A), neutrophils (B), eosinophils (C) and monocytes (D). Data were represented as means $\pm S E$. ${ }^{*}$ \# $P \leq 0.05,{ }^{* *}$, \#\# $P \leq 0.01$. Different superscripts on columns for each parameter means that they are significantly different at $P<0.05$. Preg.= Pregnant; P.P=Postpartum; Lact.=Lactating.
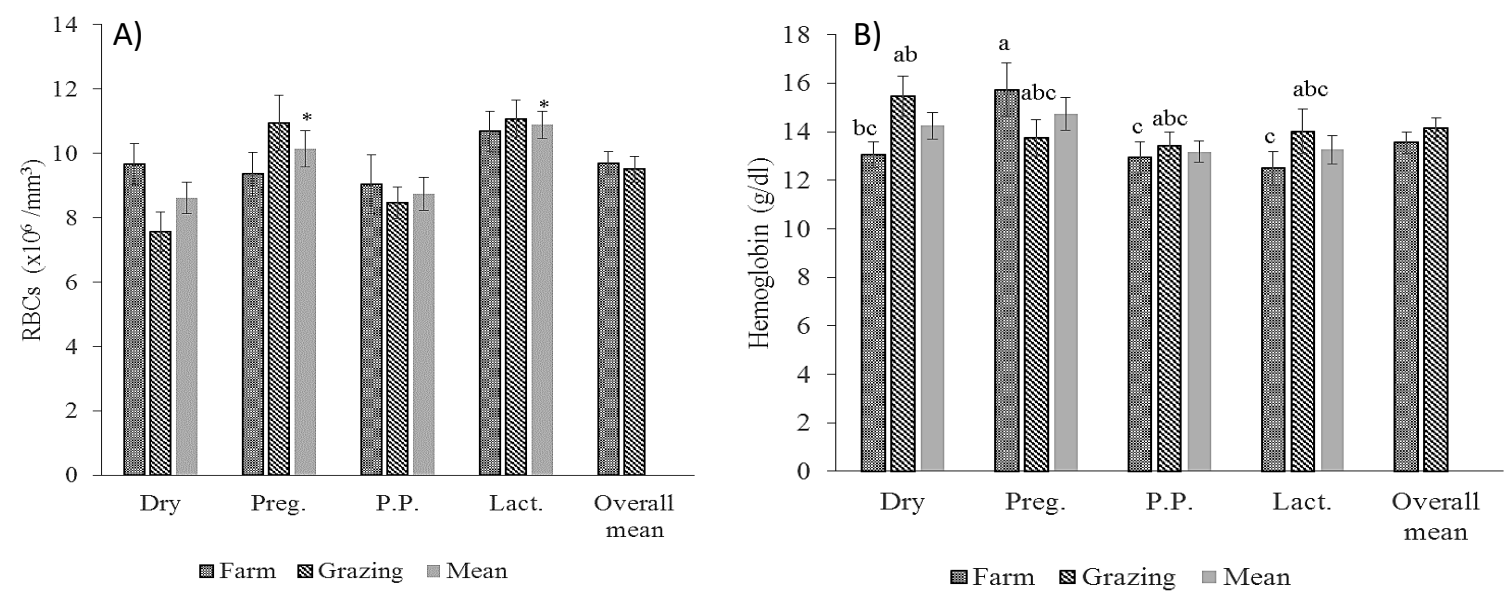

Figure 5. Effect of interaction between physiological stage and feeding system on RBCs (A) and hemoglobin (B). Data were represented as means $\pm S E$. ${ }^{*}, \# P \leq 0.05,{ }^{* *}$, \#\# $P \leq 0.01$. Different superscripts on columns for each parameter means that they are significantly different at $\mathrm{P}<0.05$. Preg.= Pregnant; $P . P=$ Post-partum; Lact.=Lactating. 


\section{Number of RBCs and $\mathrm{Hb}$ concentration}

Figure 5 showed that the management system had an insignificant effect on the number of RBCs and $\mathrm{Hb}$ levels. However, the number of RBCs increased $(P<0.05)$ in pregnant and lactating camels $\left(10.14\right.$ and $\left.10.88 \times 10^{6} / \mathrm{mm}^{3}\right)$ than dry and post-partum $\left(8.62\right.$ and $8.75 \times 10^{6}$ $/ \mathrm{mm}^{3}$ ). Contrarily, $\mathrm{Hb}$ levels showed a slight increase in dry (14.25 and $14.74 \mathrm{~g} / \mathrm{dl})$ and pregnant camels than post-partum $(13.18 \pm 0.43$ $\mathrm{g} / \mathrm{dl})$ and lactating $(13.26 \pm 0.59 \mathrm{~g} / \mathrm{dl})$.

\section{Biochemical Parameters}

\section{Plasma proteins concentrations}

As shown in Figure 6, TP concentration increased significantly $(P<0.05)$ in grazing camels $(6.87 \pm 0.13 \mathrm{~g} / \mathrm{dl})$ compared to farm ones $(6.5 \pm 0.14 \mathrm{~g} / \mathrm{dl})$. While, $\mathrm{AL}, \mathrm{GL}$ concentrations and $A / G$ ratio hadn't been affected by the management system of camels.
On the other hand, TP significantly $(P<0.05)$ increased in pregnant $(6.85 \pm 0.2 \mathrm{~g} / \mathrm{dl})$ and lactating camels $(6.87 \pm 0.25 \mathrm{~g} / \mathrm{dl})$ and decreased significantly $(P<0.05)$ in dry $(6.74 \pm 0.15 \mathrm{~g} / \mathrm{dl})$ and post-partum $(6.3 \pm 0.14 \mathrm{~g} / \mathrm{dl})$. AL concentration increased significantly $(P<0.05)$ in pregnant camels $(4.24 \pm 0.13 \mathrm{~g} / \mathrm{dl})$ compared to other physiological stages. While other plasma proteins didn't affect by the physiological status of the animals.

\section{Blood lipid components concentrations}

Interestingly, data in Figure 7 showed significant increase in plasma lipids including $T L(P<0.01)$, $P L(P<0.01)$, TG $(P<0.01)$, TC $(P<0.05)$, and LDL $(P<0.01)$ in farm camels with values being $199.5 \pm 3.09,4.48 \pm 0.54,51.3 \pm 2.28,28.32 \pm 0.93$ and $6.92 \pm 0.47 \mathrm{mg} / \mathrm{dl}$, respectively compared to grazing ones $(179.58 \pm 1.61,2.14 \pm 0.24$, $39.09 \pm 1.34, \quad 25.2 \pm 0.86, \quad 5.69 \pm 0.22 \mathrm{mg} / \mathrm{dl}$, respectively).
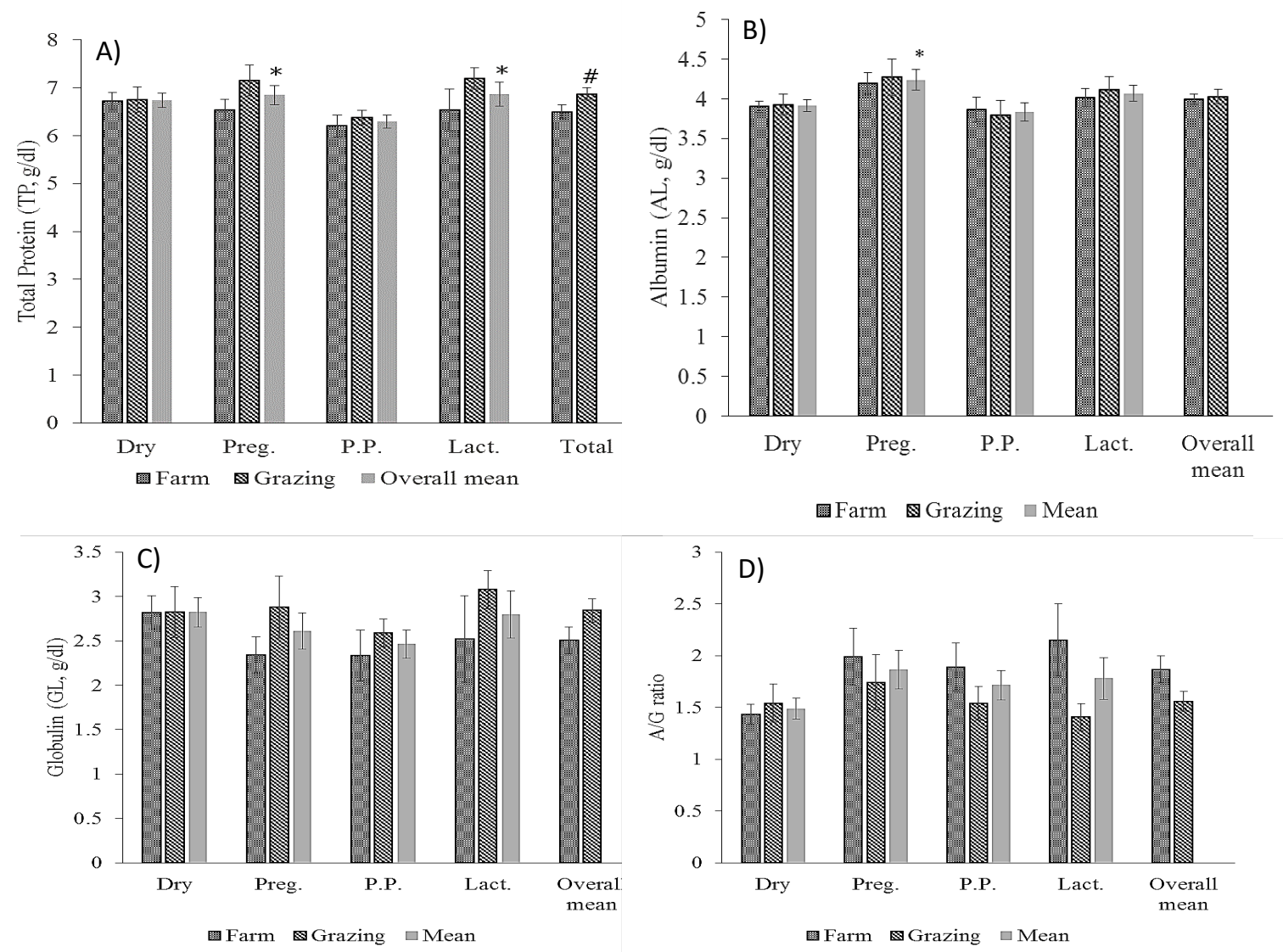

Figure 6. Effect of interaction between physiological stage and feeding system on plasma proteins. Total protein (A), albumin (B), globulin (C) and A/G ratio (D). Data were represented as means $\pm S E$. ${ }^{*}, \# P \leq 0.05,{ }^{* *},{ }^{*} P \leq 0.01$. Different superscripts on columns for each parameter means that they are significantly different at $\mathrm{P}<0.05$. Preg.= Pregnant; $P . P=$ Post-partum; Lact.=Lactating. 

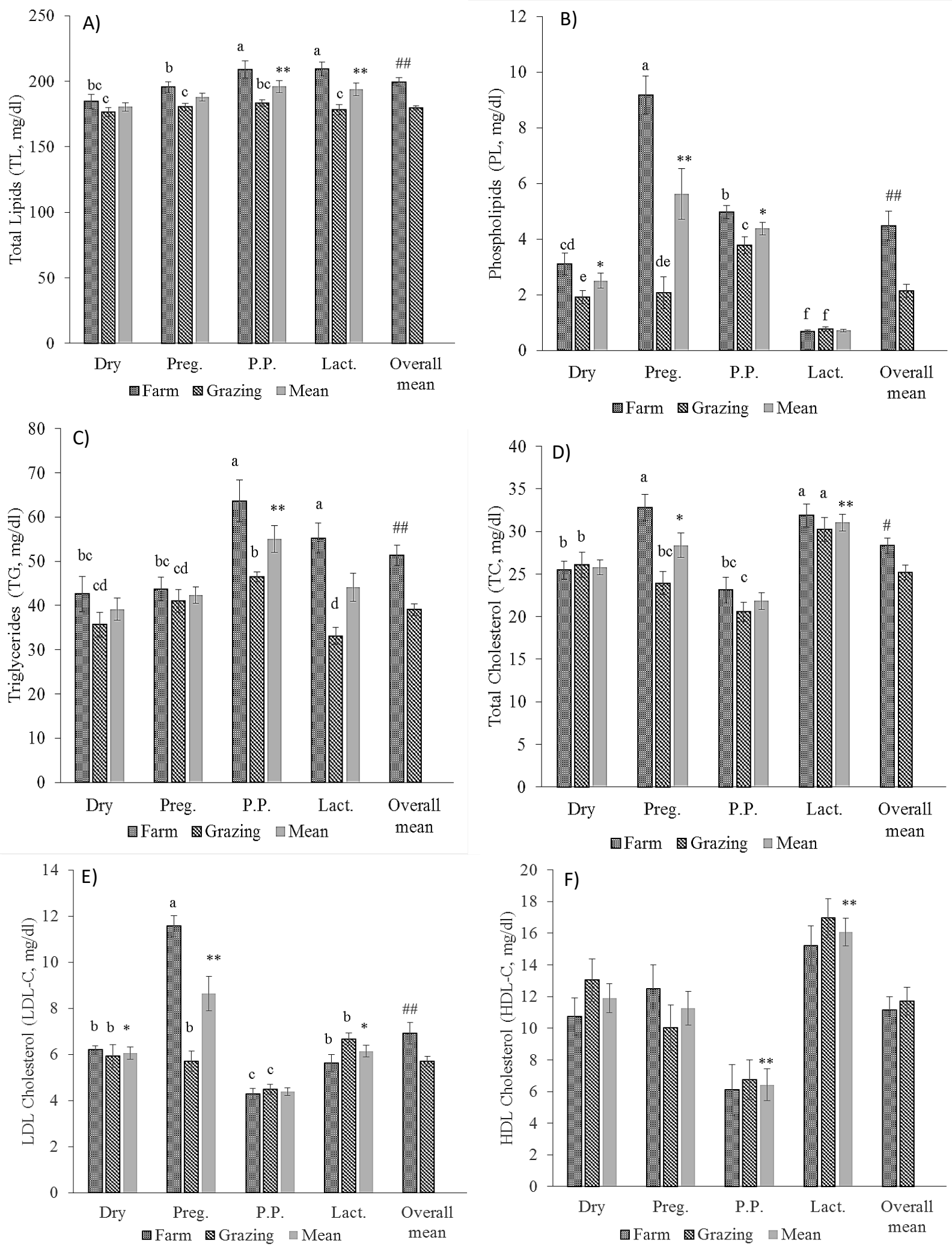

Figure 7. Effect of interaction between physiological stage and type of feeding on blood lipid profile. Total lipids (A), phospholipids (B), triglycerides (C), total cholesterol (D), LDL cholesterol (E) and HDL cholesterol (F). Data were represented as means $\pm S E$. ${ }^{*}, \# \leq 0.05,{ }^{* *}, \#$ $P \leq 0.01$. Different superscripts on columns for each parameter means that they are significantly different at $\mathrm{P}<0.05$. Preg.= Pregnant; P.P= Post-partum; Lact.=Lactating. 
On physiological level, TL showed a significant $(P<0.01)$ increase in post-partum $(195.96 \pm 4.54$ $\mathrm{mg} / \mathrm{dl})$ and lactating camels $(193.83 \pm 4.78$ $\mathrm{mg} / \mathrm{dl})$ compared to dry $(180.4 \pm 3.31 \mathrm{mg} / \mathrm{dl})$ and pregnant camels $(187.97 \pm 2.94 \mathrm{mg} / \mathrm{dl}) . \quad \mathrm{PL}$ increased significantly $(P<0.01)$ in pregnant camels $(5.62 \pm 0.92 \mathrm{mg} / \mathrm{dl})$ and decreased after parturition $(4.38 \pm 0.23 \mathrm{mg} / \mathrm{dl})$ and decreased more in lactation $(0.72 \pm 0.05 \mathrm{mg} / \mathrm{dl})$. It decreased significantly $(P<0.05)$ in lactating camels $(0.72 \pm 0.05 \mathrm{mg} / \mathrm{dl})$ compared to dry camels $(2.51 \pm 0.26 \mathrm{mg} / \mathrm{dl})$. Additionally, postpartum camels showed an increase $(P<0.01)$ in TG $(55.06$ vs. $39.15,42.37$ and $44.19 \mathrm{mg} / \mathrm{dl})$ and a decrease $(\mathrm{P}<0.05)$ in TC ( 21.83 vs. $25.78,28.38$ and $31.06 \mathrm{mg} / \mathrm{dl}$ ) compared to dry, pregnant and lactating camels, respectively. LDL increased $(P<0.01)$ in pregnant camels as compared to dry and lactating camels (8.63 vs. 6.06 and $6.14 \mathrm{mg} / \mathrm{dl})$, respectively but decreased $(P<0.05)$ in post-partum compared to other groups. Likewise, HDL values were found to follow the same trend of LDL.

\section{Concentrations of blood hormones and glucose} As shown in Figure 8, both the feeding system and physiological status were significantly affected insulin and cortisol while Glc concentration did not affect. Farm camels had a significant increase $(P<0.01)$ in cortisol than grazing $(0.22$ vs. $0.09 \mu \mathrm{g} / \mathrm{ml})$ while. Insulin had an opposite trend. The corresponding values were found to be 3.19 and $1.63 \mu \mathrm{U} / \mathrm{ml}$ in grazing and farm camels, respectively. In addition, cortisol increased $(P<0.05)$ in the post-partum period than other physiological statuses. About insulin, it increased $(P<0.05)$ in lactating camels $(4.04 \pm 0.6 \mu \mathrm{U} / \mathrm{ml})$ and decreased $(P<0.05)$ in post-partum, $(3.21 \pm 0.3 \mu \mathrm{U} / \mathrm{ml})$ compared to pregnant $(1.69 \pm 0.21 \mu \mathrm{U} / \mathrm{ml})$ and dry ones. $(0.7 \pm 0.09 \mu \mathrm{U} / \mathrm{ml})$.

\section{DISCUSSION}

Late pregnancy and early lactation are demanding physiological states that lead to significant changes in the metabolic profile in camels (Tharwat et al., 2015; Ahmed, 2017). Data in this study revealed that the management system had an insignificant effect on the leukocytic count and its differential count except for the number of lymphocytes,
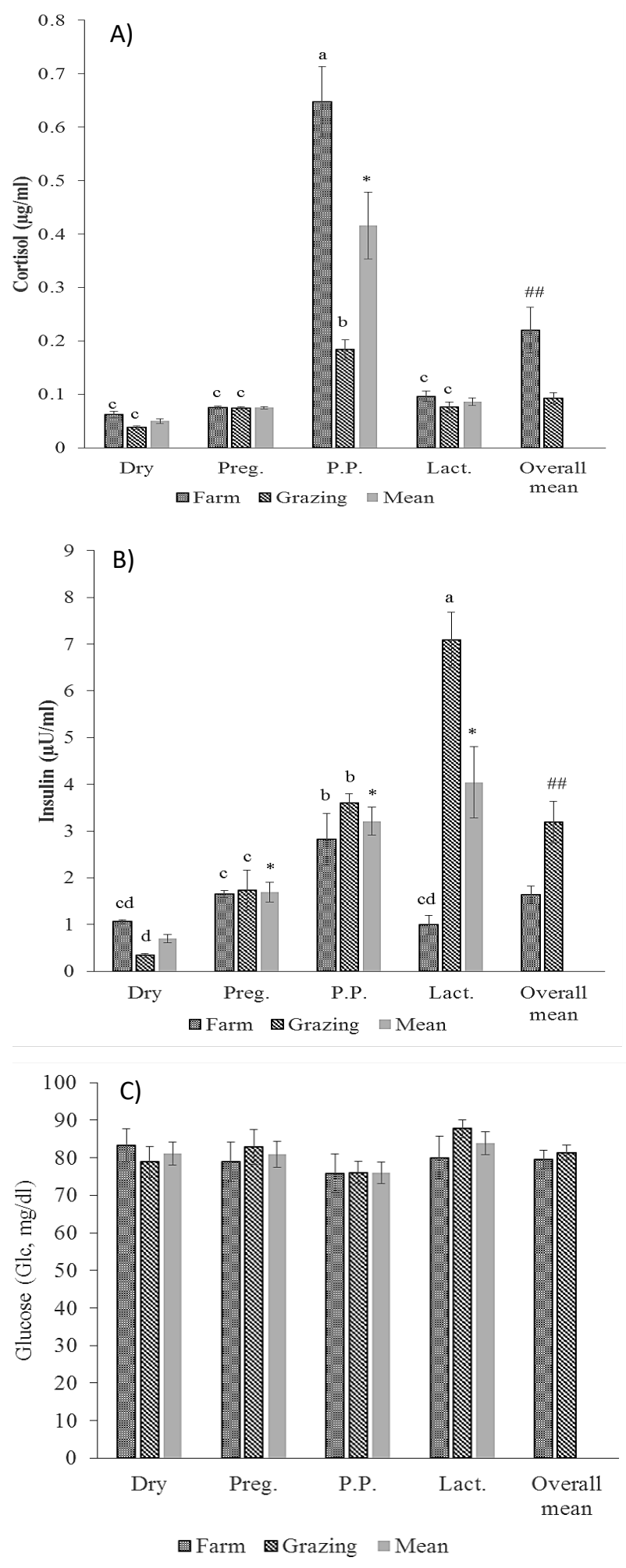

Figure 8. Effect of interaction between physiological stage and type of feeding on cortisol (A), insulin (B) and glucose (C). Data were represented as mean $\pm \mathrm{SE}$. ${ }^{*}, \# \mathrm{P} \leq 0.05,{ }^{* *}$, \#\# $P \leq 0.01$. Different superscripts on columns for each parameter means that they are significantly different at $P<0.05$. Preg.=Pregnant; $P . P=$ Post-partum; Lact.=Lactating. 
which increased $(P<0.05)$ in grazing camels than farming ones. This is consistent with Amin et al. (2007) who found that lymphocyte percentage in camels increased significantly during the dry season, while neutrophils percentage increased significantly during the green season (Babeker et al., 2013). In our study, lymphocytes are slightly higher in grazing camels but neutrophils percentage is slightly lower. This is because of the free accessibility of water for farm camels than grazing ones.

On the other hand, the physiological status has a significant effect on the number of WBCs, lymphocytes, neutrophils and monocytes, as well as, the percentages of lymphocytes, neutrophils and eosinophils. Leukocytes increased $(P<0.05)$ in post-partum compared to pregnant and dry camels. While lactating camels have increased $(P<0.05)$ in leucocytes than dry and pregnant and slight increase than post-partum. In line with these results, Abd ElSalaam and Arafa (2018) found that the number of leukocytes increased at calving compared to late-pregnancy and insignificantly increased at lactation. Muhammad et al. (2011) attributed that to physiological changes associated with fetal growth and development.

In literature, the effect of pregnancy on total leukocytes has no clear consensus. Consistent with our study, several studies showed a significant decrease in pregnant camels (Ayoub et al., 2003), cows (Nath, 2007; Nazifi et al., 2008). Other studies showed a decrease in camels (Getnet and Abebe, 2005), sheep, goats (Vihan and Rai, 1987) and Kandhari cattle (Deshpande and Sawant, 1996). However, several studies showed that the physiological status had no significant effect on WBC's count, eosinophils and basophils percentage (Tharwat et al., 2015; Elkhair and Minawy, 2018). Furthermore, the values of WBC's, eosinophils and basophils percentage did attain statistical significance during the respective physiological status, which can be considered as a good indicator for optimum management and feeding regime program for the camels investigated. In contrast, Axay et al. (2017) stated that WBC's showed lower values during early lactation compared to late lactation in camels. In addition, Muhammad et al. (2011) and Saeed et al. (2011) reported that WBC's remained unchanged during late pregnancy compared with non-pregnant camels. Also, lymphocytes percentage increased $(P<0.05)$ during late pregnancy compared to early lactation, whereas monocytes percentage increased $(P<0.05)$ in young females compared to the control, late pregnancy and early lactation ones.

On the contrary, Saeed et al. (2009) found no significant difference in leukocytes in pregnant camels. In the current study, there is a significant $(P<0.05)$ increase in the percentage of lymphocytes in lactating and dry camels than in pregnant and in post-partum camels, where it significantly $(P<0.05)$ decreased. The percentage of neutrophils significantly $(P<0.05)$ increased after parturition and decreased significantly $(P<0.05)$ in pregnant, lactating and dry camels, respectively. The number of lymphocytes showed a significant $(P<0.05)$ increase in lactating camels and decreased significantly $(P<0.05)$ in dry, pregnant and postpartum. Post-partum camels showed a significant increase in the number of neutrophils, which decreased significantly $(P<0.05)$ in lactating, as well as, significantly $(\mathrm{P}<0.05)$ decreased in dry and pregnant than the other two groups. These data are similar to those found by other investigators Ayoub et al. (2003), Getnet and Abebe (2005) and Saeed et al. (2009), who found a marked decrease in lymphocytes and an increase in neutrophils at parturition. Similar findings have been reported in sheep and goats (Vihan and Rai, 1987).

In our study, the physiological status affected significantly the percentage and number of eosinophils, which increased significantly $(\mathrm{P}<0.05)$ in post-partum and lactating and decreased significantly in pregnant and dry camels. These data are in line with Saeed et al. (2009), who found a decrease in eosinophils in pregnant camels. The eosinophil count also decreased non-significantly as observed in sheep, goats (Vihan and Rai, 1987) and Kandhari cattle (Deshpande and Sawant, 1996). The current study showed that lactating and postpartum camels had a significant increase in the number of monocytes compared to dry and pregnant camels. In contrast, Saeed et al. (2009) found a non-significant increase in monocytes in pregnant camels compared to non-pregnant. 
Current results showed that the management system had an insignificant effect on the number of RBCs and $\mathrm{Hb}$ levels. However, the number of RBCs increased significantly $(P<0.05)$ in pregnant and lactating camels than dry and post-partum. Contrarily, $\mathrm{Hb}$ levels showed a slight increase in dry and pregnant camels than post-partum and lactating ones. In the same line, Nazifi et al. (2008) demonstrated that RBCs count and $\mathrm{Hb}$ concentration were significantly higher in pregnant than in the postpartum cows. Also, other studies found that RBCs and $\mathrm{Hb}$ increased in pregnant dry cattle (Straub et al., 1959), sheep (Anosa and Ogbogu, 1979) and cows (Nazifi et al., 2008). In post-partum camels, Abd El-Salaam and Arafa (2018) indicated that no significant changes in $\mathrm{Hb}$ levels as compared to lactating ones. On the contrary, several studies found a decrease in RBCs before parturition in camel (Saeed et al., 2011), sows (Dungan et al., 1995; Žvorc et al., 2006) and goats (Azab and Abdel-Maksoud, 1999). In addition, $\mathrm{Hb}$ decreased during pregnancy in camel (Ayoub et al., 2003; Getnet and Abebe, 2005; Saeed et al., 2011) and sows (Žvorc et al., 2006). These changes in the hematological parameters were likely because of the pregnancy stress and glucocorticoid release (ACTH) from the adrenal gland (Nazifi et al., 2008).

On the other hand, the pattern of erythrocytes parameters in response to the physiological status could be attributed to increased demand for oxygen consumption and the requirements of higher metabolic rate for growth, during late pregnancy and early lactation (Elkhair and Minawy, 2018). Similar results have been observed by Abd El-Salaam and Arafa (2018) who reported higher values of $\mathrm{Hb}$ during late pregnancy in Maghrebi camels. Higher values of $\mathrm{RBC}^{\prime} \mathrm{s}$ and $\mathrm{Hb}$ have been reported during late pregnancy and early lactation in camels

From another point of view, the hyperthermia during movement under heat may induce a water loss caused by thermoregulation. This increase may be attributed to a splenic contraction rather than to dehydration. Acute exposure to stressful stimulation is manifested by a significant activation of the sympatheticadrenal medullary system, including increased synthesis, circulating levels and release of catecholamines into the circulation (McCarty et al., 1988), resulting in splenic contraction and the release of red blood cells into the circulation. This mechanism is induced by the action of catecholamines on $\alpha$-adrenergic receptors which are located in the splenic capsule (Tauler et al., 2003).

Previous studies reported that serum total protein level is usually considered as useful indices of the nutritional status of animals. The concentration of serum total protein was suggested to be increased during the dry season. This could be attributed to the stresses to which the camels were subjected under dry conditions (Amin et al., 2007; Yousif et al., 2018). As shown in our study, TP concentration increased $(P<0.05)$ in grazing camels compared to farm ones. While, AL, GL concentrations and $A / G$ ratio hadn't been affected by the management system of camels. On the other hand, TP significantly $(P<0.05)$ increased in pregnant and lactating camels and decreased significantly $(P<0.05)$ in dry and post-partum. AL concentration increased significantly $(P<0.05)$ in pregnant camels compared to other physiological stages. In contrast, Saeed et al. (2009) found that pregnant camels had lower values of TP and AL, but like our results, no change was observed in $\mathrm{GL}$ concentration in pregnant camels compared to non-pregnant ones. In line with our results, Abd El-Salaam and Arafa (2018) found that TP, AL and GL concentrations were slightly increased in late pregnancy and decreased at parturition whereas $A / G$ ratio also increased at late pregnancy and parturition that contrasted with our results. The decrease in serum total protein as parturition approaches may be attributed to the fact that the fetus synthesizes all of its proteins from the amino acids that derived from the dam, and the fetus growth increases exponentially reaching a maximum level, especially in muscles, during late pregnancy (Jainudeen and Hafez, 2000).

These results are in agreement with Roubies et al. (2006), who found that GL concentration in ewes was elevated in the last 2 months of pregnancy compared to postpartum. The observed reduction in GL concentration in postpartum may be due to the selective uptake of immunoglobulin by the mammary glands. Also, 
Tharwat et al. (2015) demonstrated that postpartum concentration of AL was decreased. The reduction in TP concentration in post-partum than in late pregnancy in camel may be due to that high level of GL transfer to the mammary glands in she-camels (Saeed et al., 2009).

Both TP and AL are markers of liver function and the decrease in their concentrations may suggest fat infiltration into the liver (Bobe et al., 2004). The AL has the water pulling and holding property and higher stimulant in camel probably show particular adjustment for the desert environment (Salman and Afzal, 2004) and it is an indication of liver function whose low focus is ascribed to fatty liver illness in dry cattle (Faramarzian et al., 2016).

Interestingly, present data showed a significant increase in plasma lipids including TL, PL, TG, TC, and LDL in farm camels compared to grazing ones. In literature, serum TG was reported to be affected by animal diet (Wasfi et al., 1987). Lipidic parameters are affected by hydration, $\mathrm{PL}$ increase (Bengoumi, 1992), TL level increases in the wet season (Mohamed, 2008) and could be modulated by the energy level of the diet (Adel and El-Metwaly, 2012). Phospholipids are a main component of the cell membrane, notably of the camel RBCs and contribute to their properties (Warda and Zeisig, 2000). In camel, PL was the major constituent of VLDL, LDL, and HDL which are important plasma lipoprotein carriers for cholesterol and triglycerides (Asadi et al., 2008). Gupta et al. (2012) confirmed that the type of diet brought to camels influences cholesterol levels. On the contrary, Faye and Mulato (1991) found a regional variability in Djibouti, the lowest TG values in blood were observed in peri-urban camel farms and the highest level was reported in the aridest areas. These authors concluded to a lower fat mobilization in non-grazing camel (Faye and Bengoumi, 2018).In the current study, TL showed a significant $(P<0.01)$ increase in postpartum and lactating camels compared to dry and pregnant ones. In agreement with these results, Saeed and Khan (2012) also noted that pregnancy did not affect the serum concentration of TL in camel.

On the physiological level, phospholipids increased significantly in pregnant camels and decreased after parturition and decrease more in lactation. It also decreased significantly in lactating camels as compared to dry camels. No data are available about this issue.

In this study, post-partum camels showed a significant $(P<0.01)$ increase in TG and a significant $(P<0.05)$ decrease in TC compared to dry, pregnant and lactating camels. In the same line, Bengoumi (1992) and Omidi et al. (2014) did not observe any significant effect for lactation and pregnancy on TG. However, Saeed and Khan (2012) found that the concentration of TG in the serum of late-pregnant camels was significantly higher than that of non-pregnant camels. But, in our study, TG was slightly higher in pregnant camels than dry ones. The increased serum triglyceride concentration in parturition had been reported for camel (Saeed and Khan, 2012), sheep (Nazifi et al., 2002) and goats (Hussein and Azab, 1998). The increase in the level of serum TG before parturition might be due to the overproduction of TG rich in V-LDL (Ward et al., 2003). In contrast, TG concentrations were higher during late pregnancy than at post-partum in cows (Folnožić et al., 2016). Also, Turk et al. (2013) observed a gradual increase in serum TG level occurred during the last month of pregnancy when compared with two months after parturition. The increase in TG concentration during post-partum and lactation periods because it is a critical source of long-chain fatty acid for milk synthesis which explains significant triglyceride diminishes at the onset of lactation (Kessler et al., 2014). Moreover, TG is an indicator of lipids profile in the blood and considered as a very important group of fat in the blood, which is the main component of very low-fat proteins in addition to chylomicrons, and is manufactured in the liver where it is stored until use as an energy source. In addition, they play an important role in the transport of dietary fats (Bagnicka et al., 2014).

In our study, lactating and pregnant camels showed a significant $(P<0.05)$ increase in TC compared to dry and post-partum. Consequent with our study, the concentration of TC was higher in late pregnancy than post-partum, being the lowest at calving (Saeed et al., 2009; Kamal, 2010; Saeed and Khan, 2012; Abd ElSalaam and Arafa, 2018). In cows, Folnožić et al. 
(2016) found that TC concentrations were higher during late pregnancy than that at postpartum months. The significant decrease in TC in late pregnancy has also been reported in other species: cows (Nath et al., 2005), goats (Krajničáková et al., 2003), and buffaloes (Prabhakar et al., 1999). This decrease in cholesterol level near the parturition could be attributed to the increased utilization for steroid synthesis around parturition. Hormonal influences might also play a major role in reducing cholesterol concentration with advancing pregnancy (Saeed and Khan, 2012). The increase in TC concentration at late pregnancy is most likely due to the increased needs of the fetus for growth and development, and also the need of the ovaries for the synthesis of steroid hormones (Turk et al., 2013). In lactating camels, Hussein et al. (1992) found that serum TC increased relatively during months of lactation.

In our study, LDL-C increased significantly $(P<0.01)$ in pregnant camels as compared to dry and lactating ones but decreased significantly $(\mathrm{P}<0.05)$ in post-partum as compared to other groups. In agreement with these findings, Miyamoto et al. (2006) reported that the concentration of LDL-C decreased significantly in cows in parturition. However, Saeed and Khan (2012) found a non-significant difference in LDL-C concentration in pregnant and nonpregnant camels.

High-density lipoproteins cholesterol (HDL-C) is responsible for the reverse transport of cholesterol from peripheral cells to the liver. Herein, cholesterol is transformed into bile acids which are excreted into the intestine via the biliary tract. Monitoring of HDL-C in serum is of clinical importance since an inverse correlation exists between serum HDL-C concentration and the risk of atherosclerotic disease (Saeed et al., 2011). In our study, the levels of serum HDL-C concentration of postpartum camels were significantly $(P<0.01)$ lower than non-pregnant, pregnant and lactating camels. LDL-C was significantly high in lactating camels compared to other physiological statuses. In line with that, several studies reported that HDL-C in pregnant camels was significantly lower than non-pregnant (Saeed and Khan, 2012; Omidi et al., 2014). In contrast,
Nazifi et al. (2002) and Hussein and Azab (1998) reported a higher value of $\mathrm{HDL}-\mathrm{C}$ concentration during late pregnancy in ewes and Baladi goats.

As shown in our data, both feeding system and physiological status significantly affected insulin and cortisol concentrations. Farm camels had a significant $(P<0.01)$ increase in cortisol than grazing ones. Contrarily, insulin significantly $(P<0.01)$ increased in grazing camels than farm ones. In the literature, the highest values of cortisol were observed during the rainy season (Bono et al., 1989). No clear impact of dehydration on insulin was observed (Siam et al., 1993) and plasma insulin concentration can be modulated by the energy level of the diet (Khazali, 2009).

In our study, cortisol was significantly $(P<0.05)$ increased in the post-partum period than in other physiological statuses. These results agree with Ibrahim et al. (2017) who reported a significant increase in serum cortisol level began from day 15 to day 1 pre-partum with a maximum level at the day of parturition. In addition, Agarwal et al., (1992) and Mohamed, (2006) demonstrated that cortisol concentrations were high at parturition and significantly decreased within the lactation period and attributed such increase to the increase of ACTH secretion from the fetal pituitary in the late pregnancy, which stimulates the rapid growth of the fetal adrenals, leading to a rise in the concentration of serum cortisol, which enters the maternal circulation and rise the maternal serum cortisol level.

With respect to insulin concentration, it increased significantly $(P<0.05)$ in lactating camels and decreased significantly $(P<0.05)$ in post-partum, which is significantly more than its level in pregnant camels. Dry camels showed a significant $(P<0.05)$ decrease in insulin levels than other groups. These findings agree with Wernery et al. (2006) who reported that higher levels of insulin occurring after 4 months of lactation.

\section{CONCLUSION}

The physiological status had a negative influence on the haematological parameters in female camels. The critical changes in the haematological parameters during the 
respective physiological status could be associated with increased requirements for growth, fetal intensive growth and lactogenesis especially for grazing camels. In addition, indigenous knowledge (identifying superior meat and milk producing and disease resistance camels, trait preferences, traditional disease treatment, best breeding and husbandry practices) of pastoral communities should be considered in the planning and implementation of smallholder camel breeding programs.

\section{CONFLICT OF INTEREST}

Authors declare that they have no conflicts of interest.

\section{FUDING}

There is no financial support for this study.

\section{REFERENCES}

Abd El-Salaam A and Arafa M (2018). Post-partum hematological, biochemical, mineral and hormonal changes in blood of Maghrebian she-camels with different parity orders under Egyptian condition. J. Agric. Vet. Sci., 11(2): 68-78.

Abdalmula AM, Buker AO, Benashour FM, Shmela ME, Abograra IM and Alnagar FA (2018). Blood profile in normal one humped dromedary (Camelus dromedarius) camel breeds in Libya. Part 1: Determination of biochemical and haematological blood profile. Journal Homepage: http://mbsresearch. com, 4(8).

Adel E and El-Metwaly H (2012). Effect of feed additive "Exogenous Enzymes" on growth performance of Maghraby Camels. Life Sci. J., 9(4): 4830-4865.

Agarwal S, Rai A and Khanna N, 1992. Hormonal studies in postpartum female camels and their neonates. Theriogenology, 38(4): 735747.

Ahmed M (2017). Effects of selenium and vitamin $E$ injection during transition period on physiological performance of camels (Camelus dromedarius) and their neonates reared under semi-intensive system. MV Sc. MVSc Thesis, University of Khartoum, Sudan, 12: 68-78.

Amin A, Abdoun KA and Abdelatif AM (2007). Seasonal variation in blood constituents of one-humped camel (Camelus dromedarius). Pakistan J. Biol. Sci., 10(8): 1250-1256.
Anosa V and Ogbogu D (1979). The effect of parturition on the blood picture of sheep. J. Res. Vet. Sci., 26(3): 380-382.

Asadi F, Shahriari A, Asadian P, Pourkabir M and Samadaei M (2008). Composition and electrophoretic mobility of plasma lipoproteins of dromedary camels (Camelus dromedarius). Am. J. Vet. Res., 69(7): 880885.

Axay J, Haque N, Lateef A, Patel A, Patel P and Bhalakiya N (2017). Study on blood metabolites and leukocyte indices of kutchi camels during different stages of lactation. J. Anim. Health Prod., 5(3): 92-96.

Ayoub M, El-Khouly A and Mohamed T (2003). Some hematological and biochemical parameters and steroid hormone levels in the onehumped camel during different physiological conditions. Emir. J. Food Agri., 15(1): 44-55.

Azab ME and Abdel-Maksoud HA (1999). Changes in some hematological and biochemical parameters during prepartum and postpartum periods in female Baladi goats. Small Rumin. Res., 34(1): 77-85.

Babeker E, Elmansoury $Y$ and Suleem A (2013). The influence of season on blood constituents of dromedary camel (Camelus dromedaries). Online J. Anim. Feed Res., 3(1): 1-8.

Bagnicka E, Jarczak J, Kaba J, JóÅowik A, Czopowlcz M and KrzyåEwski J (2014). Active dry yeast culture supplementation effect on the blood biochemical indicators of dairy goats. J. Adv. Dairy Res., 2: 1-7.

Bengoumi M (1992). Clinical Biochemistry of the Camel and its Adaptation Mechanisms to Dehydration, Ph.D. Thesis of Science, IAV Hassan II Rabat, Morocco.

Bhakat C (2019). A comprehensive study of the camel production system in the North West Coastal Zone of Egypt.

Bobe G, Young J and Beitz D, 2004. Invited review: pathology, etiology, prevention, and treatment of fatty liver in dairy cows. J. Dairy Sci., 87(10): 3105-3124.

Bono G, Dahir AM, Comin A and Jumale MA (1989). Plasma LH, corticoid and sex steroid variations in camels (Camelus dromedarius) in relation to seasonal climatic changes. J. Anim. Reprod. Sci., 21(2): 101-113.

Deshpande S, and Sawant M (1996). Leucocytes as influenced by age, sex and pregnancy in red Kandhari cattle. Indian Vet. J., 73(2): 141-145.

Duncan DB, 1955. Multiple range and multiple $F$ tests. Biometrics, 11(1): 1-42.

Dungan L, Wiest D, Fyfe D, Smith A and Swindle M (1995). Hematology, serology and serum protein electrophoresis in fetal miniature 
Yucatan swine: normal data. J. Lab. Anim. Sci., 45(3): 285-289.

Elkhair NM and Minawy AA (2018). Effect of the Physiological Status on the Haematological Parameters of Female Camels (Camelus dromedarius). J. Vet. Med. Anim. Prod., 9(2): 154 - 162.

FAO (2013). Statistical year book. Food and Agriculture Organization of the United Nations, Rome, Italy, 2013.

Faramarzian K, Haji Hajikolaei MR, Nouri M, Mohebbi M and Shahriari A (2016). Relationship between insulin to glucagon ratio and metabolic parameters in primiparous and multiparous dairy cows in transitional period. Iranian J. Rumin. Health Res., 1(1): 49-59.

Faye B (2016). The camel, new challenges for a sustainable development. Trop. Anim. Health Prod., 48(4): 689.

Faye B and Bengoumi M (2018). Camel Clinical Biochemistry and Hematology, Springer.

Faye B and Mulato C (1991). Facteurs de variation des paramètres protéo-énergétiques, enzymatiques et minéraux dans le plasma chez le dromadaire de Djibouti. J Revue d'élevage et de médecine vétérinaire des pays tropicaux, 44(3): 325-334.

Folnožić I, Turk R, Đuričić $D$, Vince $S$, Flegar-Meštrić $Z$, Sobiech $P$, Lojkić $M$, Valpotić $H$ and Samardžija M (2016). The effect of parity on metabolic profile and resumption of ovarian cyclicity in dairy cows. J Veterinarski Arhiv, 86(5): 641-653.

Getnet A and Abebe W (2005). The influence of late pregnancy and excitement on blood parameters of issa type dromedaries in estern Ethiopia. Israel J. Vet. Med., 60(4): 117.

Gupta L, Kumar RA, Ghanshyam T, Rajesh D and Garg $R$ (2012). Effect of feeding different proportions of groundnut haulms (Arachis hypogaea) and cluster bean straw (Cyamopsis tetragonoloba) on nutrient utilisation and serum biochemical parameters in dromedary camels. J. Trop. Anim. Health Prod., 44(7): 1689-1695.

Hussein M, Salah M, Mogawer H and Gar ElNabi A (1992). Effect of lactation on the haemogram and certain blood constituents of the dromedary camel. J. Appl. Anim. Res., 1(1): 43-50.

Hussein S and Azab M (1998). Plasma concentrations of lipids and lipoproteins in newborn kids and female Baladi goats during late pregnancy and onset of lactation. J DTW. Deutsche tierarztliche Wochenschrift, 105(1): 6-9.
Ibrahim MA, Abdelrahman $\mathrm{H}$ and Elmetwaly $\mathrm{H}$ (2017). Hormonal profile, antioxidant status and some biochemical parameters during pregnancy and periparturient period in dromedary she camel. Egyptian J. Vet. Sci., 48(2): 81-94.

Jainudeen M and Hafez E (2000). Gestation, prenatal physiology, and parturition. Reprod. Farm Anim.: 140-155.

Kamal AM (2010). Some biochemical, hematological and clinical studies of selected ruminal and blood constituents in camels affected by various diseases. Res. J. Vet. Sci., 3(1): 28-39.

Kessler E, Gross JJ, Bruckmaier R and Albrecht C (2014). Cholesterol metabolism, transport, and hepatic regulation in dairy cows during transition and early lactation. J. Dairy Sci., 97(9): 5481-5490.

Khazali H (2009). Effect of the galanin on growth hormone, thyroid hormones and insulin in young castrated Camelus dromedarius fed different levels of their energy requirement. J. Applied Sci., 9(15): 2822-2828.

Krajničáková M, Kováč G, Kostecký M, Valocký I, Maraček I, Šutiaková I and Lenhardt L' (2003). Selected clinico-biochemical parameters in the puerperal period of goats. J Bull. Vet. Inst. Pulawy, 47: 177-182.

McCarty R, Horwatt K and Konarska M (1988). Chronic stress and sympathetic-adrenal medullary responsiveness. Social Sci. and Med., 26(3): 333-341.

Miyamoto T, Sugiyama $Y$, Suzuki J, Oohashi T and Takahashi Y (2006). Determination of bovine serum low-density lipoprotein cholesterol using the N-geneous method. J Vet. Res. Commu., 30(5): 467-474.

Mohamed H (2006). Factors affecting cortisol status in camels (Camelus dromedarius). J. Anim. Vet. Adv., 5(4): 307-309.

Mohamed H (2008). Factors affecting the plasma lipid status in camels (Camelus dromedaries). Res. J. Biol. Sci., 3(4): 444-445.

Muhammad B, Aliyu D, Njidda A and Madigawa I (2011). Some haematological, biochemical and hormonal profile of pregnant and nonpregnant she-camels (Camelus dromedarius) raised in a Sudan savanna zone of Nigeria. J. of Camel Practice Res. Vet. Sci., 18(1): 73-77.

Nath H, Baruah K, Baruah A, Sarmah H and Sarmah B (2005). Serum cholesterol and protein in pre, peri and postpartum cows. Indian veterinary journal, 82(5): 519-521.

Nath R (2007). Haemato biochemical parameters of pregnant and non-pregnant crossbred cows. Indian Vet. J., 84(10): 102-103. 
Nazifi S, Ahmadi M and Gheisari H (2008). Hematological changes of dairy cows in postpartum period and early pregnancy. J. Comp. Clin. Pathol., 17(3): 157-163.

Nazifi S, Saeb M and Ghavami S (2002). Serum lipid profile in iranian fat-tailed sheep in late pregnancy, at parturition and during the postparturition period. J. Vet. Med. Ser. A, 49(1): 9-12.

Omidi A, Sajedi Z, Torbati MBM and Nik HA (2014). Lipid profile and thyroid hormone status in the last trimester of pregnancy in singlehumped camels (Camelus dromedarius). Trop. Anim. Health Prod., 46(4): 609-614.

Prabhakar S, Nanda A and Ghuman S (1999). Sequential changes in some blood indices during peripartal period in buffaloes. Indian Vet. J., 76(12): 1067-1070.

Roubies N, Panousis N, Fytianou A, Katsoulos P-D, Giadinis N and Karatzias $H$ (2006). Effects of age and reproductive stage on certain serum biochemical parameters of Chios sheep under Greek rearing conditions. J. Vet. Med. Ser. A, 53(6): 277-281.

Saeed A, Khan I and Hussein M (2009). Change in biochemical profile of pregnant camels (Camelus dromedarius) at term. Comp. Clin. Pathol., 18(2): 139-143.

Saeed A and Khan IA (2012). Alterations in serum lipids and lipoproteins profile of pregnant camels (Camelus dromedarius) at term. Comp. Clin. Pathol., 21(5): 1019-1021.

Saeed A, Khan IA and Hussein MM (2011). Change in haematological profile of pregnant camels (Camelus dromedarius) at term. Comp. Clin. Pathol., 20(1): 53-55.

Salman R and Afzal M (2004). Seasonal variations in hematological and serum biochemical parameters in racing camels. J. Camel Sci., 1: 63-65.

Schalm OW, Jain NC and Carroll EJ (1975). Veterinary Hematology, Lea and Febiger.

Siam A, Ahmed M, Mohamed W and Ismail A (1993). Plasma levels of glucose and insulin in camels during dehydration. Alex. J. Vet. Sci., 9(3): 9396.

Simeneh K (2015). Characterization of Camelus Dromedarius in Ethiopia: production systems, reproductive performances and infertility problems, Doctoral dissertation.

Straub O, Schalm O, Hughes J and Theilen G (1959). Bovine hematology. II. Effect of parturition and retention of fetal membranes on blood morphology. J. Am. Vet. Med. Asso., 135: 618622.
Tauler P, Aguiló A, Gimeno I, Fuentespina E, Tur JA and Pons A (2003). Influence of vitamin C diet supplementation on endogenous antioxidant defences during exhaustive exercise. Euro. J. of Physio., 446(6): 658-664.

Tharwat M, Ali A, Al-Sobayil F, Selim L and Abbas H (2015). Haematobiochemical profile in female camels (Camelus dromedarius) during the periparturient period. J. Camel Pract. Res. Vet. Sci., 22(1): 101-106.

Turk R, Podpečan O, Mrkun J, Kosec M, FlegarMeštrić Z, Perkov S, Starič J, Robić M, Belić M and Zrimšek P (2013). Lipid mobilization and oxidative stress as metabolic adaptation processes in dairy heifers during transition period. Anim. Reprod. Sci., 141(3-4): 109-115.

Vihan V and Rai P (1987). Certain hematological and biochemical attributes during pregnancy, parturition and post-parturition periods in sheep and goats, Indian J. Anim. Sci., 57: 1200-1204.

Ward KJ, Shields B, Knight B, Salzmann MB, Hattersley AT and Frayling TM (2003). Genetic variants in Apolipoprotein AV alter triglyceride concentrations in pregnancy. Lipids in Health and Disease, 2(1): 9-10.

Warda M and Zeisig R (2000). Phospholipid-and fatty acid-composition in the erythrocyte membrane of the one-humped camel [Camelus dromedarius] and its influence on vesicle properties prepared from these lipids. DTW. Deutsche tierarztliche Wochenschrift, 107(9): 368-373.

Warden M (2004). The nutrient requirements of the dromedary camel. J. Camel Sci., 1: 37-45.

Wasfi I, Hafez A, el Tayeb F and El Taher A (1987). Thyroid hormones, cholesterol and triglyceride levels in the camel. Res. Vet. Sci., 42(3): 418-418.

Wernery U, Johnson B and Ishmail WT (2006). Insulin content in raw dromedary milk and serum measured over one lactation period. J. Camel Pract. Res., 13(2): 89-90.

Yousif HS, Omer SA, Ahmed SH and Fadlalmola SA (2018). The Effect of Pregnancy, Management and the Environmental Condition on Blood Metabolites, Leukocytic and Erthrocytic Indices and Clinical Parameters in Butana Camels - Sudan. Nat. Sci. , 16(12): 162-173.

Žvorc Z, Mrljak V, Sušić V and Pompe Gotal J (2006). Haematological and biochemical parameters during pregnancy and lactation in sows. Veterinarski arhiv, 76(3): 245-253. 


\section{Egyptian Association for Cancer Research (EACR)}

http://eacr.tanta.edu.eg/

EACR is an NGO society that was declared by the Ministry of Social Solidarity (Egypt) No. 1938 in 19/11/2014 based on the initiative of Prof. Mohamed Labib Salem, the current Chairman of EACR. EACR aims primarily to assist researchers, in particular young researchers in the field of cancer research through workshops, seminars and conferences. Its first international annual conference entitled "Anti-Cancer Drug Discovery" was successfully organized in April 2019 (http://acdd.tanta.edu.eg). Additionally, EACR aims to raise the awareness of the society about the importance of scientific research in the field of cancer research in prediction, early diagnosis and treatment of cancer. EACR is also keen to outreach the scientific community with periodicals and news on cancer research including peer-reviewed scientific journals for the publication of cutting-edge research. The official scientific journal of EACR is "International Journal of Cancer and biomedical Research (IJCBR: https://jcbr.journals.ekb.eg) was successfully issued in 2017 and has been sponsored by the Egyptian Knowledge Bank (EKB: www.ekb.eg).

\section{EACR Chairman,}

Prof. Mohamed Labib Salem, PhD

Professor of Immunology

Faculty of Science, Tanta Universiy, Egypt 
International Journal of Cancer and Biomedical Research (IJCBR), a publication of the Egyptian Association for Cancer Research (EACR), is a peer-reviewed online journal published quarterly. The journal allows free access (Open Access) to its contents and permits authors to self-archive a final accepted version of the articles on any OAl-compliant institutional / subject-based repository.

\section{Aim And Scope}

Aim: The main aim of IJCBR is to attract the best research in animal and human biology in health and diseases from across the spectrum of the biomedical sciences at the molecular, cellular, organ, and whole animal levels especially those that are related to cancer research, including causes, prediction, diagnosis, prognosis and therapy.

Scope: It is essential reading for all researchers interested in biochemistry, cancer, microbiology, nutrition, physiology, genetics, immunology, epidemiology, medical economics, human biology, bioinformatics, biotechnology, nanotechnology, and disease modeling.

\section{Publication Ethics}

Researchers should conduct their research from research proposal to publication in line with the best practices and codes of conduct of relevant professional bodies and/or national and international regulatory bodies. IJCBR accepts manuscripts prepared in accordance with the "Uniform Requirements for Submission of Manuscripts for Biomedical Journals adopted by the International Committee of Medical Journal Editors (ICMJE) and the Committee on Publication Ethics (COPE). Details of ICMJE and COPE are available at http://www.icmje.org/ and http://publicationethics.org/

\section{Peer Review Process}

After the IJCBR editor receives a manuscript, the first step is to confirm that the manuscript meets the journal's rules for content and format, including similarity check (plagiarism) which should be less than $25 \%$. If the manuscript meets the journal's rules, the editor then assign it to the double-blind peer review process. The IJCBR editor send the manuscript to at least two experts in the field for RIGOROUS scientific evaluation. The experts called peer reviewers - will then prepare a report that assesses the manuscript and return it to the editor through the IJCBR portal. Upon the first submission, this reviewing process takes about 4 to 6 weeks. After reading the peer reviewer's report, the editor will decide one of the following four options:

1. Reject the manuscript.

2. Accept the manuscript

3. Ask the authors to revise and resubmit the manuscript after responding to the peer reviewers' feedback.

4. Ask for peer-review from additional reviewers.

If the authors resubmit the manuscript, the IJCBR editor will ask the same peer-reviewers to look over the manuscript again to confirm that their concerns have been addressed. This is called re-review process. This second revision (if applicable) takes about another 4 to 6 weeks. At this point, the abstract of the article appears in press. The online publication (the PDF format) of the final version of the manuscript takes from 2 to 4 weeks. As such, the total publication cycle takes from 2 to 4 months. This cycle can be reduced to 4 to 6 weeks (fast track publication) for the manuscripts with outstanding findings.

The peer-review process used by IJCBR includes comments on errors in the study's methods or analysis that raise questions about the findings, or sections that need clearer explanations. The peer-review process also includes the importance and novelty of the manuscript and its interest to the journal's audience. The IJCBR uses double-blind review, which means that both the reviewers and authors identities are concealed from the reviewers, and vice versa, throughout the review process. To facilitate this, authors need to submit a Title Page containing the Authors details and Blinded Manuscript with no author details as 2 separate files. 


\section{Publisher}

The International Journal of Cancer and Biomedical Research (IJCBR) is an International and interdisciplinary journal of preclinical and clinical studies in the area of cancer and biomedical research. It is a peer-reviewed journal in English, published quarterly (in March, June, September, and December) by the Egyptian Association for Cancer Research (EACR) in both print and online formats (4 issues making a volume). Special issues or supplements may also be produced from time to time upon agreement with the Editorial Board.

\section{Scope}

The main aim of IJCBR is to attract the best research in animal and human biology in health and diseases from across the spectrum of the biomedical sciences at the molecular, cellular, organ, and whole animal levels especially those that are related to cancer research, including causes, prediction, diagnosis, prognosis and therapy.

\section{Publication Fees}

The journal does charge for submission, processing or publication of manuscripts (2000 LE for Egyptians or $\$ 300$ for non-Egyptians; EACR members receive 15\% discount on publication). Of them Peer-review fees (300 LE) should be paid on submission (non-refundable). For the fast track production of the accepted manuscript, another $500 \mathrm{LE}$ is paid.

General specifications for different types of article

- Submitted manuscripts should not have been published previously, except in a limited form (e.g. short communication to a symposium or as part of MSc or PhD theses) and should not be under consideration for publication by other journals.

- All co-authors should agree with the content of the manuscript. Authors must have obtained permission to use any copyrighted material in the manuscript before submission.

\section{IJCBR publishes different types of articles}

- Original Article (6000 words with $\mathbf{4}$ tables and $\mathbf{4}$ figures, maximum $\mathbf{8}$ display items): Articles with novel findings are the target of IJCBR. Articles presenting a detailed description of a new technique, comparison of existing methods, meta-analyses with comprehensive and in-depth discussion are considered. Papers in a numbered series are not accepted unless all are submitted at the same time.

- Short communications or case study (3000 words with 4 display items): Short communications present exceptionally exciting, novel or timely contents are considered. They will be peer-reviewed in the same way as research papers. The references are restricted to 15 .

- Reviews or systematic review (9000 words with $\mathbf{1 0}$ display items): They are invited by the Editorial Board or unsolicited. Review articles have to be contemporary and comprehensive and add information to the knowledge. Sharp critical analyses of novel data or concepts are encouraged. When relevant, a statistical analysis of data and a meta-analysis approach are recommended.

- Opinion papers, letter to the editor or comment to the editor (1500 words with $\mathbf{2}$ display items): They are submitted by invitation of the Editorial Board. They are short papers, which aim to inform scientists, industry, and the public and policymakers about cutting-edge issues in research or the impact of research. They reflect the opinion of their authors who bear full responsibility of the published paper. The references are restricted to 10 .

- Conference/Symposium papers: The journal will consider for publication the results of original work and critical reviews that are presented at conferences/symposia. Symposium organizers who wish to publish bundles of papers from a symposium/conference in IJCBR should first contact the Editor-inChief of the IJCBR (EACR@unv.tanta.edu.eg) for agreement. Supplementary material can be proposed and will be made available online. The responsibility for the preparation of a paper in a form suitable for publication lies with the author.

- Thesis: IJCBR can publish the summary and abstract of Master and PhD theses in a special issue. 
English: Good quality of written English is required. Spelling may be in British or American English but must be consistent throughout the paper. Care should be exercised in the use of biological terminology that is ill-defined or of local familiarity only. We recommend that authors have their manuscripts checked by an English language native speaker before submission.

Manuscript layout: Manuscripts should be prepared using a standard word processing program and presented in a clear readable format with easily identified sections and headings. The manuscript layout is based on the following directions.

- The main text contains Title, Abstract, Keywords, Introduction, Material and Methods, Results, Discussion, References, Tables, figures.

- The title needs to be concise and informative. Use bold, with an initial capital for the first word only and for words that ordinarily take capitals

- Short (running) title (max 80 characters including spacing).

- The article text should be typed with double-line spacing with wide margins $(2.5 \mathrm{~cm})$.

- The lines must be continuously numbered; the pages must also be numbered.

- Font Calibri 12 should be used for the text, and 12 for the tables, figure legends and references.

- The sections should typically be assembled in the following order:

- Title page contains title, authors' names, full affiliations, acknowledgements and the corresponding author's contacts and Short title.

Abstract (max 250 words, single paragraph): The abstract should be complete and understandable without citation, references, table or figure. Use structured abstract: Background, Aim, Materials \& Methods, Results and Conclusion. The context and the rationale of the study are presented succinctly to support the objectives. The experimental methods and main results are summarized but should not be overburdened by numerical values or probability values. The abstract ends with a short and clear conclusion.

Keywords: Up to five short and specific keywords should complement the title with respect to indicating the subject of the paper in alphabetic order.

Introduction: The introduction briefly outlines the context of the work, presents the current issues that the authors are addressing and the rationale to support the objectives, and clearly defines the objectives.

Material and methods: Material and methods should be described in sufficient details so that others can repeat the experiment. Reference to previously published work may be used to give methodological details, provided that said publications are readily accessible and in English. The code of ethics should be followed for all experiments use animals or human samples.

Statistical analysis of results: The statistical design and the models of statistical analysis must be described, as well as each of the statistical methods used. Sufficient statistical details must be given to allow replication of the statistical analysis. The experimental unit should be defined (e.g. individual or group of animals).

Results: Data are presented as tables and figures. Brief description of the results for each table and figure should be presented. Unpublished data can be mentioned when necessary.

Discussion: Should be separate from the Results section and should focus only on intra- and inter-data discussion (the data in the results section) as well as with the relative data in the literature. Don't repeat information already presented in the Introduction section. Start the first paragraph in the Discussion with a paragraph stating the rationale behind the study, the objectives and the main findings. End Discussion with a short conclusion.

Acknowledgements: In this section, the authors may acknowledge (briefly) their support staff.

Conflict of interest: All papers with a potential conflict of interest must include a description/explanation in a separate heading.

Funding details: The authors should state the source of findings of the study (with research funder and/or grant number). If no fund, the authors should state that the study is self-funded. 


\section{References}

Citation of references: In the text, references should be cited by the author(s) surname(s) and the year of publication (e.g. Salem, 2020). References with two authors should be cited with both surnames (e.g. Salem and Meshrif, 2021). References with three or more authors should be cited with the first author followed by et al. (in italics; e.g. Salem et al., 2021). Names of organizations used as authors (e.g. Food and Drug Administration) should be written out in full in the list of references and on the first mention in the text. Subsequent mentions may be abbreviated (e.g. FDA).

- List of references. Literature cited should be listed in alphabetical order by authors' names. It is the author's responsibility to ensure that all references are correct. All authors should be written and so the full journal name.

- References from journal articles are formatted in APA as this example: Al-Amoudi WM (2018). Toxic effects of Lambda-cyhalothrin on the rat thyroid. Involvement of oxidative stress and ameliorative effect of ginger extract. Toxicology Reports, 5: 728-736.

- References from books or official reports are formatted as this example. Kebreab E, Dijkstra ANM, Bannink A, Gerrits WJJ, \& France J (2006). Nutrient digestion and utilization in farm animals. CABI Publishing. Wallingford, UK.

- References from chapters or parts of books are formatted as this example. Nozière $P, \&$ Hoch $T$ (2006). Modelling fluxes of volatile fatty acids from rumen to portal blood. In: Nutrient digestion and utilization in farm animals (Kebreab E, Dijkstra ANM, Bannink A, Gerrits WJJ \& France J, eds.), pp. 40-47. CABI Publishing. Wallingford, UK.

Tables:

The data should be presented in tables or in graphs, not both.

- Each table should be placed on a separate page at the end of the main text.

- Tables are numbered consecutively using Arabic numbering. They are referred to as Table 1 , Table 2, etc., with capital ' $T$ ', no italics

- Each table has its explanatory caption. The caption is sufficient to permit the table to be understood without reference to the text.

- Abbreviations used in tables/figures have to be defined either as footnotes or in the caption.

Figures

- Package the figures in a single PowerPoint file. Each figure in a separate slide.

- Figure size should be readable in a width of approximately 8-175 $\mathrm{mm}$ (i.e. the maximum size of printing over two columns).

- Ensure that the font size is large enough to be readable at the final print size, use Calibri font to ensure that they are consistent throughout the figures.

- The figures should preferably be provided as TIFF or EPS files.

- The resolutions of figures must be at least $300 \mathrm{dpi}$.

- Preparation of images for a manuscript: For guidance, we refer to the Journal of Cell Biology's instructions to authors (http://jcb.rupress.org/site/misc/ifora.xhtml\#image_aquisition).

- If a cropped image is included in the main text of a paper (e.g. a few lanes of a gel), display the full original image, including the appropriate controls, the molecular size ladder and/or the scale as relevant, as a single figure in a Supplementary Material file to facilitate peer-review and for subsequent online publication.

- Supplementary material is submitted along with the main manuscript in a separate file and identified at uploading as "Supplementary File - for Online Publication Only" The title of the article is included at the top of the supplementary material.

Corresponding author's guidelines: Upon acceptance the corresponding author is required to send his/her recent formal photo to be attached to the front page of the article. 


\title{
International Journal of Cancer \& Biomedical Research
}

(IJCBR) Online ISSN 2682-2628

\author{
Editor-in-Chief \\ Mohamed Labib Salem, PhD \\ Tanta University, Egypt
}

\begin{tabular}{l} 
EACR Board \\
\hline Nehal Elmashad, MD \\
Tanta University, Egypt \\
Nabil Mohy Eldin, PhD \\
Kafrelsheikh University, Egypt \\
Doaa Al-Ghareeb, PhD \\
Alexandria University, Egypt \\
Abdel-Aziz Zidan, PhD \\
Damanhour University, Egypt
\end{tabular}

\begin{tabular}{l} 
Managing Editor \\
\hline Wesam Meshrif, PhD \\
Tanta University, Egypt \\
Sohaila Galal, PhD \\
Tanta University, Egypt \\
Production and Contact \\
\hline Hamdi Kandil \\
Tanta University, Egypt \\
Email: ljcbr100@gmail.com
\end{tabular}

\section{Advisory Board}

Alberto Montero, MD

Taussig Cancer Center, Cleveland,

USA

Yi Zhang, MD

Zhengzhou University, China

Mark Robunstein, Ph D

Medical University of South

Carolina, USA

Mohsen Farid, Ph D

Derby University, USA

Natarajan Muthusamy, Ph D

Ohio State University, USA

Hideki Kasuya, MD

Nagoya University, Japan

Sherif El-Khamisy, Ph D

Sheffield University, UK

Mohamed Ghanem, Ph D

Kafr Elshikh University, Egypt

Sayed Bakry, Ph D

Alazhar University, Egypt

Sameh Ali, Ph D

Nationa Liver Institute, Egypt

Gamal Badr, Ph D

Assuit University, Egypt

Nadia Hamdy, Pharm D

Ain Shams University, Egypt

\section{Editorial Board}

\section{Clinical studies}

Hesham Tawfik, MD

Tanta University, Egypt

Mohamed Attia, MD

Tanta University, Egypt

Mohamed Elshanshory, MD

Tanta University, Egypt

Essam Elshiekh, MD

Tanta Cancer Center, Egypt

Rasha Eraky, MD

Tanta University, Egypt

Shaima Abou-Kjatwa, MD

Tanta University, Egypt

Marcela Diaz, MD

Cleveland Clinic Foundation, USA

Mohamed Abou-El-Enein, MD

Charité Universitätsmedizin Berlin,

Germany
Alaa Eldin Almostafa, MD

McGill University, Canada

Olfat Gadallah, MD

Tanta University, Egypt

Nagla Sarhan, MD

Tanta University, Egypt

Naglaa Fathy, Pharm D

Zagazik University, Egypt

Mohamed Salama, MD

Mansoura University, Egypt

Mona Marie, MD

Alexandria University, Egypt

Preclinical studies

Mostafa El-Sheekh

Tanta University, Egypt

El-Refai Kenawy, Ph D

Tanta University, Egypt

Mohamed Noureldin, Ph D

Banaha University, Egypt

Yousry Albolkiny, Ph D

Tanta University, Egypt

Elsayed Salim, Ph D

Tanta University, Egypt

Shengdian Wang, Ph D

Chinese Academy of Sciences,

China

Sabry El Naggar, Ph D

Tnata Univesity, Egypr

Faris Alenzi, Ph D

Prince Sattam bin Abdulaziz

University, KSA

Ibrahim El-Sayed, Ph D

Menoufia University, Egypt

Tarek Aboul-Fadl, Ph D

Assiut University, Egypt

Rabab Khairat, Ph D

National Research Center,

Giza, Egypt

Wael Lotfy, Ph D

Alexandria University, Egypt

Ashraf Tabll, Ph D

National Research Center, Egypt

Nahla Shoukry, Ph D

Suez University, Egypt
Medhat Eldenary, Ph D

Tanta University, Egypt

Azza Hasan, Ph D

Menufia University, Egypt

Nanees Gamal Eldin, Ph D

Tanta University, Egypt

Mohamed Mansour, UK

Sabbah Hammoury, Ph D

Alexandria Ayadi Almostaqba

Oncology Hospital, Egypt

Nehal Aboulfotoh, Ph D

Zewail City for Science and

Technology, Cairo, Egypt

Amir Elkhami, Ph D

Galaxo, San Francisco, USA

Ahmed Alzohairy, Ph D

Zagazi University, Egypt

Wgady Khalil, Ph D

National Research Center, Egypt

Amr Amin, Ph D

United Arab Emirates

University, UAE

AbdelRahman Zekri, Ph D

National Cancer Institute, Egypt

Hussein Khamis, Ph D

Alexandria University, Egypt

Magdy Mahfouz, Ph D

Kafr Elsheikh University, Egypt

Ehab Elbedewey, Ph D

Tanta University, Egypt

Abeer Badr, Ph D

Cairo University, Egypt

Mamdooh Ghoneum, Ph D

Charles Drew University of

Medicine \& Science, USA

Haiam Abou Elela, Ph D

National Institute of Oceanography and Fisherie, Egypt

Maha EL-Demellawi, Ph D City for Scientific Research \&

Technology Applications, Egypt

Desouky Abd-El-Haleem, Ph D

City for Scientific Research \&

Technology Applications, Egypt 